УДК 339.94(497.1)"1964"

339.923:061.1CEB(4-664)

DOI https://doi.org/10.31212/tokovi.2020.3.nin.139-163

Оригинални научни рад

Примљен: 24. 8.2020.

Прихваћен: 1. 10. 2020.

Momir N. NINKOVIĆ

momirninkovic22@gmail.com

\title{
Establishment of Cooperation Between the SFRY and the COMECON in 1964*
}

\begin{abstract}
This article analyzes the motives for establishing cooperation between Yugoslavia and the Council for Mutual Economic Assistance (COMECON). The course of the negotiations is shown, as well as, the conclusion of the Agreement on Yugoslavia's participation within the organs of the COMECON. The paper is based on unpublished documents from the archives of the Republic of Serbia and the Russian Federation, as well as other relevant literature.

KEY WORDS: Yugoslavia, Council for Mutual Economic Assistance, The Soviet Union, Economic Integration
\end{abstract}

With the exchange of letters between the Yugoslav Embassy's charge d'affaires, Feliks Gorski and the secretary of the Council for Mutual Economic Assistance (COMECON, CMEA), Nikolai Vasilievich Fadeyev, which was conducted on September 17, 1964, at the COMECON Secretariat in Moscow, the Socialist Federal Republic of Yugoslavia (SFRY, Yugoslavia) established cooperation with the socialist economic integration. ${ }^{1}$

* The author expresses his gratitude to Đurađ Đurić for the translation of this article into English.

1 In the media and in literature, different formulations are used ("special observer", "observer", "associate member", "partial membership", "incomplete membership") to describe the status of the SFRY within the COMECON, is characterized in a non-precise manner. It wasn't about "any sort of a membership," but about "specific cooperation on issues mutual interest, which was regulated with a sui generis agreement." Srećko Đukić, Ekonomska saradnja SFRJ i SEV, (Beograd: Zadruga, 1984), 95; Александар Ћирић, „Привредно-правни аспекти двадесетогодишњице сарадње СФРЈ-СЕВ“, 
With that act, the Agreement on the participation of the SFRY within the organs of the COMECON was concluded, which represented the groundwork on which the cooperation between Yugoslavia and the CMEA would be based in the decades to follow. Overall, in the next 25 years, the CMEA had an extremely important, "stable" second place in Yugoslavia's foreign (the Western-European countries were in first place, primarily members of the European Economic Community). Beside foreign trade, which represented the "most developed form of cooperation," the relations between the SFRY and the CMEA also involved cooperation and specialization, scientific-engineering cooperation, and the "credit-financial sphere." In order to perceive completely the relations between the SFRY and the CMEA in the period between the mid-sixties and the beginning of the nineties, it is necessary to process, in a historiographical ${ }^{3}$ manner, the question of Yugo-

Зборник радова Правног факултета у Нишу, XXV, ур. Мирослав Миљковић, (Ниш: Правни факултет Универзитета у Нишу, 1985), 202; Trajan Bendevski, „Neka pravno-teorijska pitanja saradnje SFRJ-SEV“, Saradnja SFRJ-SEV. Principi - aktuelna pitanja - perspektive. Materijali jugoslovenskog naučno-stručnog skupa povodom 20 godina saradnje SFRJ-SEV, ur. Ljubivoje Prvulović, (Beograd: Institut za međunarodnu politiku i privredu, 1987), 234-239; Budimir I. Lazović, Ekonomska integracija u okviru Savjeta za uzajamnu ekonomsku pomoć, (Beograd: Vaša knjiga, 2005), 216-217.

2 Đukić, Ekonomska saradnja, 93-148; Тирић, „Привредно-правни аспекти“, 202-210; Saradnja SFRJ-SEV; Lazović, Ekonomska integracija, 216, 218-220, 251-253; Ненад Поповић, Ондреј Јашко, Спољнотрговински односи и перспективе привредне сарадње Руске Федерације и Републике Србије, (Београд: Српски економски центар, 2010), 164-169.

3 The study about the relations between the SFRY and the COMECON was here mostly performed by economists, political scientists and lawyers, and the lack of historiographic research is noticeable. Almost every relevant paper was published in the period before the dissolution of the COMECON. Since the beginning of the nineties, that topic has been practically "forgotten." Such a state of affairs is only partially comparable to affairs abroad. Until the end of the 2000s, the COMECON had not attracted any greater attention of researchers in other countries. However, since that period, there was an increased interest, which culminated last year when a series of scientific conferences were organized, regarding the 70th anniversary of the foundation of the COMECON. More on contemporary research about the COMECON: Михаил Аркадьевич Липкин, „Совет Экономической Взаимопомощи и современные тренды в изучении XX века: К 70-летию образования СЭВ“, Studia Slavica et Balcanica Petropolitana 2/2019, 56-66. Unlike the times before the beginning of the nineties, when the papers about the relations of the SFRY and the COMECON were formed on a relatively narrow source basis (published documents and official announcements, data from statistics and periodicals, convenient publications), today - in the country, as well as, abroad - a large amount of relevant sources are available. Also, unlike the period of socialist Yugoslavia, researchers today do not have the "burden" of any personal experience, commitments or responsibility which was a part of working in a state institution or authority in the times of the active cooperation between the SFRY and the COMECON. With incentives that come from other historiographies, the two matters stated above represent a solid basis for the histo- 
slavia's accession to socialist economic integration: to understand the motivations of Belgrade and Moscow(!) for establishing cooperation and the context in which Yugoslavia and the CMEA were brought closer together; to process the course, content, and outcome of the negotiations in 1964.

Before we start deliberating on the events of 1964, certain "introductory notes" should be given and the establishment of cooperation between the SFRY and the CMEA should be placed in a corresponding context. In the first place, it should be clear that the relations between the SFRY and the CMEA were completely dependent on the relations between Belgrade and Moscow. Since the foundation of the CMEA at the beginning of 1949, until the Agreement in September of 1964, the relationship of this organization toward Yugoslavia strictly followed all the ups and downs in the Yugoslav-Soviet relationship. ${ }^{4}$ In that "zigzag" motion and the alternating shift of ups and downs, in the spring of 1962, a new phase began in relations between Yugoslavia and the CMEA: the perennial decline had been stopped and a gradual ascent had begun which - two and a half years later - led to the Agreement on the participation of Yugoslavia within the organs of the COMECON. Such a motion was dependent on the development of Yugoslav-Soviet relations in the period between 1962. and 1964. The constant "ascending path" in the relations between Moscow and Belgrade was the main reason and the precondition that enabled the establishment of cooperation in September of $1964 .{ }^{5}$ Another important matter, for the understanding of Yugoslavia and the CMEA getting closer and starting their cooperation during the first half of the sixties, were Moscow's plans for overcoming the "territorial limitation of the

riographic interpretation of the topic about the cooperation between the SFRY and the COMECON.

4 Diplomatski arhiv Ministarstva spoljnih poslova Republike Srbije (Diplomatic Archives of the Ministry of Foreign Affairs of the Republic of Serbia - DAMSPRS), Politička arhiva (PA), 1959, fascikla 91, dosije 9, 435076 (91/432-91/433), Donošenje Statuta Saveta za uzajamnu ekonomsku pomoć; Ibid, 1962, f. 99, dos. 3, 442873, Aktuelni problem SEV-a, 26. 3. 1962.

5 More on the rise of Yugoslav-Soviet relations in the period between 1962 and 1964: Соня Вреск, Советский Союз и Югославия: проблемы политического взаимодействия в 1955-1971 г2., (диссертация на соискание ученой степени кандидата исторических наук, Санкт-Петербургский государственный университет, 2011), 137-149; Đoko Tripković, Jugoslavija-SSSR 1956-1971, (Веоgrad: ISI, 2013), 139-152. 
CMEA" and it's spread to other socialist countries. Among the potential new members of the CMEA, which were being considered in Moscow in 1962, alongside the socialist countries of Asia and Cuba, Yugoslavia had also been mentioned. ${ }^{6}$ Belgrade's aspiration for establishing cooperation with the COMECON was - partially, not entirely - consistent with such Soviet plans. Even though it was not a total overlapping of interests (the SFRY didn't want to become a member of the CMEA but only to cooperate with that organization on matters that represented "mutual interest"), those two aspirations - along with other factors - were convergent enough to lead to the establishment of cooperation.

The third important factor that had affected the joining of Yugoslavia and the CMEA, were the difficulties Belgrade was having in economic relations with the Western world. At the beginning of the sixties, Yugoslavia had "high debt obligations" to the Western world, its credit structure was "unfavorable" and "inadequate," and during 1962, its debt payment condition had gotten worse and had created the chronic Yugoslavian problems of a negative payment balance even more difficult. ${ }^{7}$ At the beginning of the sixties, relations with the United States had also gotten worse, which led to abolishing the "mechanisms of economic and financial aid to the Yugoslav economy" in 1962. ${ }^{8}$ A particular concern in Belgrade was caused by "integration organizations" in Western Europe. In the eyes of the Yugoslavs, they represented a "very negative factor," which created "difficulties" with the export of Yugoslav products (especially agricultural). "A special kind of problem" was the European Economic Community, which the Yugoslav leaders felt was leading an "exclusive and discriminative policy."

6 М. А. Липкин, „,'Мировой кооператив народов': Совет экономической взаимопомощи, который пытался построить Н. С. Хрущев“, Новый исторический вестник 4/2017, 130-131.

7 DAMSP, PA, 1961, f. 60, dos. 2, 416855, B. Crnobrnja - predstavništvima FNRJ u istočnoevropskim državama, 29. 5. 1961; Ibid, 1962, f. 59, dos. 5, 411558, Cirkularni telegram Koče Popovića - svim predstavništvima, 9. 4. 1962; Ibid, 424470, Državni sekretarijat za inostrane poslove (DSIP) - ambasadama FNRJ u Vašingtonu, Parizu, Londonu, Bernu, Rimu, Briselu, Hagu, Oslu, Stokholmu, Kopenhagenu, Bonu; generalnim konzulatima u Minhenu i Hamburgu i Vojnoj misiji u Berlinu, 25. 7. 1962; Ibid, f. 121, 416982, Mićunović, Ambasadi u Vašingtonu, 25. 5. 1962.

8 More on this: Dragan Bogetić, „Uvođenje američkih ekonomskih restrikcija Jugoslaviji tokom 1962 - ukidanje statusa 'najpovlašćenije nacije'“, Istorija 20. veka 1/2009, 87-105; Милан Ј. Игрутиновић, „Југословенско-амерички економски односи (1954-1968)“, (докторска дисертација, Универзитет у Београду, Филозофски факултет, Одељење за историју, 2018), 219-245.

9 DAMSP, PA, 1962, f. 121, 416982, Mićunović, Ambasadi u Vašingtonu, 25. 5. 1962; Arhiv Jugoslavije (Archives of Yugoslavia - AJ), Kabinet predsednika Republike (KPR), I-3-a/101-33, Zajedničko tržište i njegove reperkusije; Ivan Obadic, "A troubled re- 
Facing such conditions in the West, Belgrade decided to seek out an "exit" in both directions - "with regional routing" of foreign trade and economic relations toward the "nonaligned" countries of the Third World and toward the Eastern European countries, members of the CMEA. ${ }^{10}$

The fourth factor, important for understanding Yugoslavia gravitating toward the COMECON, was Belgrade's concerns regarding the "limitations" that stemmed from strengthening integration processes within the CMEA. ${ }^{11}$ The Yugoslavs were realizing that a "dynamic process of economic cooperation and distribution of work" and "deepening of integration processes" were happening in the CMEA. They were also noticing that the coordination of economic plans for the CMEA members was being "conducted intensely" and that "subsequent fitting" into the plans would not provide "equality of [...] cooperation": priority was given to the countries that were COMECON members, so it was frequently pointed out to the Yugoslavs that certain products had been "distributed among the CMEA countries and that there was nothing more left" or that they would have to wait a long time for those products. In turn, the Yugoslavs were "finding themselves in a situation in which [...] trade with the USSR and the other countries was adding on and only marginally fitting into already prepared frames and schemes, which had been established inside this organization." That is why the SFRY tried to enable a "timely fitting" of their needs into CMEA plans. From 1962 through 1964 there was a "significant increase, both in volume and in form" of Yugoslavia's economic cooperation with the members of the CMEA, but it was not "adequate according to the existing possibilities and needs." Therefore, it was "difficult to secure the expansion of economic cooperation" with the members of the CMEA "without a long-term division of work, without an insight into the complex development of these countries' economics and without any longterm perspective and security in the development of economic relations." In the Yugoslav analysis, it was pointed out that the "forms of an entirely bilateral economic cooperation" with the members of the CMEA did not enable any significant development of economic relations and it was stat-

lationship: Yugoslavia and the European Economic Community in détente", European Review of History 2/2014, 332-333.

10 DAMSP, PA, 1962, f. 59, dos. 5, 411558, Cirkularni telegram Koče Popovića - svim predstavništvima, 9. 4. 1962; AJ, KPR, III-B-1-a, Informacija o rebalansu plana uvoza roba i nerobnih rashoda za 1962. godinu, 26. 4. 1962.

11 More on integration processes in COMECON, in that period: М. А. Липкин, „'Мировой кооператив народов'“, 121-144. 
ed that the "existing bilateral features" needed to be "supplemented and expanded with united multilateral forms." ${ }^{12}$

Apart from economic, there were certain political calculations that pointed to the establishment of cooperation between the SFRY and the CMEA. Such a "motivation" was more characteristic of Moscow than of Belgrade. On the Soviet side, they felt that the process of the "gradual involvement of Yugoslavia into the socialist distribution of work through the CMEA" - along with strengthening of economic connections between the USSR (and other Eastern European countries) and Yugoslavia - would also have a "significant influence on the Yugoslav economy from the point of view of strengthening socialist methods and forms of leadership, as well as contributing to a further weakening of foreign economic connections between Yugoslavia and the Western world." They felt that support had to be given to "Yugoslavia's new orientation toward closer economic ties to the USSR and the other socialist countries" and that this would "further show a very positive effect on changing the Yugoslav Government's current position in international affairs." ${ }^{13}$ The Eastern European officials spoke to the Yugoslavs about the "need for Yugoslavia to come closer to the CMEA," pointing out, at the same time that "political impediments for Yugoslavia's tighter bonding with the socialist camp were becoming fewer and fewer"; they were expressing their hope that the Yugoslavs would "soon become members of the CMEA and that establishing relations between the League of Communists of Yugoslavia and the socialist camp's parties would eventually happen"; during the discussions, they were "throwing around" questions about Yugoslavia's "membership in the CMEA" - but even more than that, about "their membership in the

12 AJ, Fond 130, fascikla 656, arhivska jedinica 1087, Saradnja SFR Jugoslavije sa SEV-om, Radna grupa za pregovore sa SEV-om, 21.12. 1963; AJ, Fond 837, KPR, I-3-a/101-32, Zabeleška o razgovoru J. B. Tita sa ambasadorom SSSR-a Jepiševim 26. 3. 1962; Ibid, I-3-a/101-33, Ekonomski problemi; Isto, III-b-2-a, Naši odnosi sa Savetom za uzajamnu ekonomsku pomoć, april 1962; Ibid, Informacija o našim ekonomskim odnosima sa socijalističkim zemljama Istočne Evrope, 31. 10. 1963; DAMSP, PA, 1962, f. 99, dos. 3, 444136, Odnosi Jugoslavija-SEV; Ibid, 442570, Bez naslova (Referat o odnosima FNRJ I SEV-a), 13. 1. 1962; Ibid, f. 127, dos. 9, 443023, Razgovor Koča-Gromiko, 20. 4. 1962; Ibid, 1963, f. 108, dos. 5, 442952, Informativni razgovori sa SEV-om i izveštaj, 15. 7. 1963; Ibid, 1963, 442101, Predlog za uspostavljanje naših odnosa sa SEV-om, 18. 1. 1963.

13 Российский государственный архив новейшей истории (РГАНИ), Ф. 5 (Аппарат ЦК КПСС), ОП. 49, Д. 519, Л. 292-293, О советско-югославских экономических отношениях, 15. 12. 1962. 
socialist camp" - while presenting it all along as if Yugoslavia had already "stepped inside with one foot,"14

Such matters were a reflection of the (constant) aspirations and broader efforts to get Yugoslavia as near as possible into the "socialist camp." Even though this was something that wasn't related entirely to the COMECON, it was obvious that the thinking existed that such a path could influence Yugoslavia's politics. The Yugoslavs characterized such expectations - expectations of "more thorough reconsideration about our relationship toward the socialist camp," the aspiration toward a "tighter bonding of Yugoslavia," the intention to influence the "internal development" of the SFRY ("getting them back on the right path") and the "desire to drag Yugoslavia into being a CMEA member" - as a "high degree of illusions" and called them "unrealistic political combinations." ${ }^{15}$ However, the Yugoslavs had similar "calculations" as well. Namely, in Belgrade, it was considered that "cooperation with the CMEA is providing opportunities to carry out and affirm the principles of our socialist construction and, to a certain degree, affect the positive processes that were happening in many socialist countries." ${ }^{16}$ Therefore, there were intentions (or at least a reasoning) on both sides that certain political interests could be realized "under the umbrella" of the CMEA. Despite the final range those intentions had in the decades that followed, those questions deserve to be researched in greater detail, after which it would become clearer whether or not they were only "illusions."

Since the spring of 1962, Yugoslavia's gradual advance toward the COMECON created prerequisites for leading negotiations and establishing cooperation during 1964. Of special importance were the "informative conversations" that took place in the middle of 1963 at the COMECON Sec-

14 DAMSP, PA, 1962, f. 99, dos. 1, 418744, Ambasada u Budimpešti, DSIP-u, 4. 6. 1962; Ibid, dos. 2, Ambasada u Sofiji, DSIP-u, 5. 7. 1962; Ibid, 1963, f. 108, dos. 1, 48082, Ambasada u Varšavi, DSIP-u, 7. 3. 1963.

15 Ibid, 1962, f. 99, dos. 1, 418744, Ambasada u Budimpešti, DSIP-u, 4. 6. 1962; Ibid, 1964, f. 181, dos. 12, 417209, Beleška o pripremama za razmatranje nacrta sporazuma o saradnji sa SEV-om, 20. 4. 1964; AJ, KPR, I-3-a/101-33, Neke napomene u vezi sa posetom A. Gromika Jugoslaviji.

16 DAMSP, PA, 1964, f. 181, dos. 12, 413876, Izveštaj o pregovorima sa SEV-om, 13. 2. 1964. 
retariat (June 24-29, 1963). ${ }^{17}$ The Federal Executive Council (FEC) adopted the Yugoslav delegation's report from the negotiations on October 23, 1963 and the "suggestions regarding cooperation with the CMEA." The willingness on the Yugoslav side to approach the negotiations on the "specific forms and terms of cooperation" was announced to the COMECON Secretariat in December. At its X session held in Bucharest in late 1963, the CMEA Executive Committee (EC) accepted the Yugoslav proposal for cooperation and "decided unanimously" to enter into negotiations. ${ }^{18}$ Thus, 1964 began with mutual consent for the start of negotiations on establishing cooperation. On January 8, the Yugoslav ambassador in Moscow handed a note to the secretary of the COMECON, with a request from the FEC to start the negotiations. On that occasion N. Fadeyev announced that the COMECON's EC "greeted with pleasure" the desire of the FEC and suggested that the Yugoslav delegation "arrive somewhere around January 20, for a specific agreement regarding the areas and forms of cooperation." ${ }^{19}$

The negotiations between the two sides were performed in an "open and friendly atmosphere" at the COMECON's Secretariat in the period between January 25 and February 3, 1964. Augustin Papić, the state undersecretary in the federal secretariat for foreign trade, was the head of the Yugoslav delegation, while the head of the COMECON's Secretariat representatives was Nikolai Fadeyev. At the very beginning of the negotiations the "basic legal and organizational principles were considered and set, as the starting point for future cooperation between Yugoslavia and the CMEA." Also implemented was a "closer introduction" of the Yugoslav delegation to the activities of certain standing committees, for which the SFRY expressed an interest, and the "tasks and organization of the International Bank," which started its work on January 1,1964 and whose activity was "concentrated on introducing multilateralism into the CMEA". The

17 Ibid, 1963, f. 108, dos. 5, 442952, Informativni razgovori sa SEV-om i izveštaj, 15. 7. 1963; Российский государственный архив экономики (РГАЭ), Ф. 561 (Секретариат Совета экономической взаимопомощи), Оп. 42c, Д. 44, Л. 70-76, Информация о результатах обсуждения в Секретариате СЭВ вопроса о возможных формах участия Югославии в работе органов Совета, 4. 7. 1963.

18 AJ, KPR, III-b-2-a, Informacija o našim ekonomskim odnosima sa socijalističkim zemljama Istočne Evrope, 31. 10. 1963; AJ, 130-656-1087, Saradnja SFR Jugoslavije sa SEV-om, Radna grupa za pregovore sa SEV-om, 21. 12. 1963; DAMSP, PA, 1963, f. 108, dos. 4, 437344, DSIP, Ambasadi SFRJ u Moskvi, 21. 11. 1963; Ibid, 439669, Ambasada u Moskvi, DSIP-u, 7. 12. 1963; Ibid, 1964, f. 181, dos. 11, 4311, Ambasada u Bukureštu, DSIP-u, 31.12. 1963.

19 Ibid, 1963, f. 108, dos. 4, 441696, DSIP, Ambasadi SFRJ u Moskvi, 28. 12. 1963; Ibid, 1964, f. 181, dos. 11, 4988, Ambasada u Moskvi, DSIP-u, 9. 1. 1964. 
representatives of the CMEA - according to the words of the head of the Yugoslav delegation - "endeavored to present as broad an explanation as possible, necessary for setting the postulates and principles of the works of various commissions, as well as, the new bank." Based on the insight and knowledge they had gained during the negotiations, members of the Yugoslav delegation stated in their report that the "matters that are being studied in the committees, with which we will actively cooperate" were "of great interest for our economy." During the negotiations the CMEA officials noted that the mode of cooperation that was suggested by the Yugoslavs was "new to them and they never cooperated with any country in such a manner (except the involvement of some countries entirely as observers)." That is why both sides sought corresponding solutions "with joint efforts" which would - in accordance with the CMEA statute - "regulate" cooperation. "Two types of cooperation" were agreed - the first concerned the "active cooperation" and resolving specific matters in areas and committees for which the Yugoslav side expressed an interest; the second implied the "Yugoslavia's involvement in the work of some committees as an observer."

Based on the suggestions from the Yugoslav side, it was agreed that the "collaborative relations between the SFRY and the CMEA would be regulated with an agreement." For negotiation purposes, the Yugoslav delegation had a prepared "draft" of the agreement. However, "the representatives of the CMEA did not have the authority to access a more definitive regulation of cooperation (drafting the agreement)," which is why the two sides put together "a memorandum" that contained the principles of cooperation around which an agreement was established. It was stated in the "memorandum" that the two sides had agreed that Yugoslavia would cooperate "within the frames of the CMEA" in matters that represent a "mutual interest for the SFRY and the CMEA member-states," specifically: in the areas of foreign trade, currency-financial matters, black and colored metallurgy, mechanical engineering, the chemical industry, and scientific-technical cooperation. There was a possibility of "expanding the cooperation to other areas, where mutual interest was shown." It was agreed that the cooperation, before all, happens within the corresponding standing committees of the COMECON, where the Yugoslav representatives could suggest the consideration of "matters which are of interest for Yugoslavia," to participate in discussions about such topics and have "advisory voting rights." A possibility was left that the representatives of the SFRY could also participate in "sessions of those working or- 
gans of the standing COMECON committees and other Council organs," when discussing issues that concerned Yugoslavia. In case some "issues in which Yugoslavia participates" get to be considered by the "higher organs" ("Council session or Executive Committee meeting"), Yugoslavs "can participate in the meetings of those organs." It was agreed that the "the recommendations and decisions on matters of mutual interest" could be adopted "only by members of the CMEA" but doing so, the opinion of the Yugoslav representatives would be taken into consideration, which would, "in a suitable way," subsequently confirm the "consent with the recommendations from those organs." According to the opinion of the CMEA representatives, it allowed the Yugoslav side to "practically decide to accept or not to accept certain recommendations," depending on and according to their best interests.

In addition to the stated "active form of cooperation," the two sides also agreed that the SFRY representatives - as observers - "can participate in the works and meetings of other committees as well, for the purpose getting acquainted with their activities." Based on that, it was further possible to "expand the areas of active cooperation" (in the report of the Yugoslav delegation, it was pointed out that the "observer position in other CMEA committees" can be of "great significance" for the SFRY, precisely because of that). With the "memorandum," the "exchange of views, information, and materials on a mutual basis" was also stipulated. It was roughly agreed that the Yugoslav Government would compensate "part of the expenses related to the preparation of materials for the meeting of Council authority and the expenses of the services for those meetings."

Having in mind the former "conversations and information about the works of the CMEA," the introduction with the "work plans" for 1964, and the development of economic relations between the SFRY and the CMEA members, the Yugoslavs partially "concretized" the issues in which they were expecting the establishment of cooperation. It was stated in the "memorandum" that the Yugoslav party "expressed interest" for establishing cooperation in the following areas: 1) foreign trade and "currency-financial relations" ("the conclusion of long-term and annual agreements on trade, considering the expansion of trade, mutual settlements and payments, ways of negotiated regulations of commercial and industrial relations"); 2) industrial cooperation, i.e. specialization and cooperation in black metallurgy ("metal problems, raw materials, coal for coking materials of weaker quality, steel and ferroalloys, rolled materials and pipes"), colored metallurgy ("problems of producing and processing of colored 
metals, ore beneficiation, securing the need for rare metals, replacement of non-ferrous metals") and mechanical engineering ("machine tools, heavy engineering, and power plants, tractors and agricultural machines, railway vehicles, the automobile industry"); 3 ) "matters of radio engineering and electronics"; 4) chemical industry ("organic and non-organic chemistry, plastics, man-made fibers, mineral fertilizers and plant protection products, pharmaceutical industry"); 5) a broad area of topics in scientific research. It was emphasized that the mentioned "areas and topics" were listed "tentatively" and that the Yugoslav side would, "through cooperation, getting acquainted with plans and through the work of some organs, be able to modify and expand the area of the above-mentioned propositions" (in the report of the Yugoslav delegations, it was emphasized that the "real source of problems for active cooperation" would be able to get executed "only when a full insight into the plans of some committees was available, which would be possible after signing the cooperation agreement"). ${ }^{20}$

The head of the Yugoslav delegation pointed out that the "basic areas of cooperation were cleared with these negotiations" and that only the "principles of cooperation," which were presented in the "memorandum," should be transferred to the Agreement. It was agreed upon that both delegations present their authorities - FEC and COMECON's EC - the "memorandum" for consideration. In the case of mutual consent, after the EC meeting (which was set for February 25, 1964), the COMECON Secretariat would put together a "draft agreement" and deliver it to the Yugoslavs "at the beginning of March." After that, the submission of "an agreed draft" would follow, for consideration at the next COMECON EC meeting, planned for April. After the confirmation on the meeting, COMECON EC could execute the signing of the agreement. ${ }^{21}$

20 DAMSP, PA, 1964, f. 181, dos. 11, 41145, Savezni sekretarijat za spoljnu trgovinu, DSIP-u, 13. 1. 1964; Ibid, 45287, Pitanja koja će se postaviti u vezi regulisanja saradnje sa SEV-om, 18. 1. 1964; Ibid, 44458, Ambasada u Moskvi, DSIP-u, 5. 2. 1964; Ibid, dos. 12, 412384, Telegram Lalovića - predstavništvima SFRJ u Varšavi, Pragu, Budimpešti, Bukureštu, Sofiji i Berlinu, 13. 2. 1964; Ibid, 413876, Izveštaj o pregovorima sa SEV-om, 13. 2. 1964; Ibid, Promemorija o rezultatima razmene mišljenja izvršene u Sekretarijatu SEV 25, 29. januara i 1. februara ove godine sa delegacijom Vlade SFRJ o pitanjima učešća Jugoslavije u radu organa Saveta, Sekretarijat SEV, 3. 2. 1964; РГАЭ, Ф. 561, ОП. 44c, Д. 30, Л. 25-29, Памятная записка о результатах обмена мнениями, имевшего место в Секретариате СЭВ 25, 29 января и 1 февраля с. г. с делегацией правительства СФРЮ по вопросу участия Югославии в работе органов Совета.

21 DAMSP, PA, 1964, f. 181, dos. 11, 44458, Ambasada u Moskvi, DSIP-u, 5. 2. 1964; Ibid, dos. 12, 412384, Telegram Lalovića - predstavništvima SFRJ u Varšavi, Pragu, Bu- 
The COMECON Secretariat prepared and sent the necessary documentation to the permanent representatives of the member countries, immediately after the end of the negotiations, so the matter could be considered at the XI meeting of EC. ${ }^{22}$ The Yugoslav delegation stated in the report from the negotiations that they felt that the "basic principles and settings" that had been agreed upon and entered into the "memorandum," could: 1) serve "as a serious basis for specific cooperation on certain economic matters"; 2) "provide an opportunity for getting acquainted with the problems of the economic development and integration aspirations of these countries"; 3 ) "provide the terms for such cooperation through which the problems that appeared so far in the bilateral economic relations could be solved to the mutual benefit". Because of all of this, the delegation suggested that the FEC "considers and approves the settings presented in the agreed Memorandum of the two delegations" and - "after the CMEA Executive Committee approved the Memorandum" - to "consider and adopt an agreement on cooperation with the COMECON." ${ }^{23}$ At the session held on March 7,1964, the Yugoslav Government agreed with the suggestions and conclusions from the delegation's report. ${ }^{24}$

On the other hand, at the XI meeting of the COMECON's EC, held in late February of 1964, the representatives of all of the countries "in principle, once again, welcomed cooperation" with the SFRY. On that occasion, a "really short" discussion was conducted and remarks were presented that were mostly "of a technical nature." The only "significant" remark was made by a Romanian representative who did not agree with the "article that stipulates the contract being signed by the delegation of the SFRY Government and the COMECON Secretariat, but instead between the Secretariat and the representatives of the governments of all the COMECON members, i.e. the heads of all the delegations in the EC." ${ }^{25}$ At the EC

dimpešti, Bukureštu, Sofiji i Berlinu, 13. 2. 1964; Ibid, 413876, Izveštaj o pregovorima sa SEV-om, 13. 2. 1964.

22 РГАЭ, Ф. 561, Оп. 44c, Д. 4, Л. 287-302, Н. Фаддеев - Постоянным Представителям стран в СЭВ, 5. 2. 1964.

23 DAMSP, PA, 1964, f. 181, dos. 12, 413876, Izveštaj o pregovorima sa SEV-om, 13. 2. 1964.

24 Ibid, dos. 11, 47617, Izvod iz zapisnika sa sednice SIV-a u užem sastavu, održane 7. 3. 1964; Ibid, 48000, DSIP, Ambasadi u Moskvi, 16. 3. 1964.

25 Also, in the period to come, the Romanians were firmly opposed that "Fadeyev signs the convention on behalf of the COMECON member's governments" because they considered that it would mean "they acknowledge to COMECON and Fadeyev the rights of a superorganism over the governments," which would "open the doors for a next, big step in that direction". DAMSP, PA, 1964, f. 181, dos. 12, 419639, Ambasada u Bukureštu, DSIP-u, 30. 4. 1964. More about Romania's position with- 
meeting "the document about the cooperation of the SFRY and the CMEA was, in principle, accepted" and a firm stance was taken that the cooperation Agreement should be "entirely along the lines of a jointly drafted document." Because of the fact that the planned Agreement represented "a precedent for the other countries," the EC passed a decision that the COMECON's Secretariat, the deputies of the permanent representatives, and the experts from the member-states, should re-consider the text, go over the "legal details," and put together "a final suggestion for the contract." The CMEA representatives informed the Yugoslavs that there "will not be any deviating from what had been agreed" but that it was only about "specifying the details" and some "purely procedural matters." According to their estimate from the beginning of March, the Agreement could have been signed already "around April 20."26

In mid-March, the COMECON Secretariat sent a "specified" project of the Agreement to the representatives of the member-states for "approval." After the consent of the permanent representatives regarding the text of "the specified project" - according to the words of N. Fadeyev - the Secretariat "could start negotiations with the representatives of the SFRY with the aim of making a coordinated [...] Agreement project," which would then be presented for consideration at the XII meeting of the EC. In late March and early April the representatives of the member-states "generally approved the specified Agreement project" and the only specific remark was with regard to the way in which it was to be signed - the Romanians reiterated. ${ }^{27}$ Upon receiving the consent, COMECON's Secretariat handed the Yugoslav Embassy in Moscow the Agreement project in early April, specifying the "mutual rights and obligations during the cooperation." The Secretariat asked the Yugoslavs to study the project and send their remarks as soon as possible (in the case of any "more serious remarks" it was pos-

in COMECON and the reasons for such a stance from Bucharest: Анна Сергеевна Гладышева, „Советские планы экономической интеграции в рамках СЭВ и позиция румынского руководства (середина 1950-х-середина 1960-х гг.)“, Электронный научнообразовательный журнал “История", 2015, Т. 6. Выпуск 11 (44), 1-29, accessed 16. 3. 2017, http://hIbidry.jes.su/s207987840001341-4-1.

26 РГАЭ, Ф. 561, Оп. 44c, Д. 30, Л. 41, Н. Фаддеев - Постоянным Представителям стран в СЭВ, 28. 2. 1964; Ibid, Л. 43, К вопросу об участии Социалистической Федеративной Республики Югославии в работе органов Совета Экономической Взаимопомощи, 4. 4. 1964; DAMSP, PA, 1964, f. 181, dos. 11, 46870, Ambasada u Bukureštu, DSIP-u, 3. 3. 1964; Ibid, 46772, Ambasada u Moskvi, DSIP-u, 6. 3. 1964; Ibid, dos. 12, 415627, Papić (iz Ženeve), DSIP-u, 4. 4. 1964.

27 РГАЭ, Ф. 561, Оп. 44с, Д. 30, Л. 30-38, Н. Фаддеев - Постоянным Представителям стран в СЭВ, 14.3.1964; Ibid, Оп. 48, Д. 239, Л. 8-9, И. о. Секретаря СЭВ И. Ружичка - Постоянным Представителям стран в СЭВ, 3. 4. 1964. 
sible to carry out negotiations, on April 10-15, about the compliance of the draft Agreement). The harmonized text was to be accepted at the XII Meeting of COMECON's EC, scheduled for April 21, 1964. ${ }^{28}$

Even though it was said in Belgrade that "there were no significant changes in the draft agreement, from what we have established earlier" and what the FEC had approved at its meeting of March 7, the answer from Yugoslavia was not received before the April meeting of COMECON's EC. There were certain economic reasons for the answer to be sent before the EC's session because the question of "conforming national plans of economic growth before 1970" was a current issue at that time. Until the end of April the "bilateral fulfillment of five-year plans" was supposed to be finished, after which a discussion at committees should have been conducted (until the end of 1964), and "the final adoption of plans" was planned for 1965. It was extremely important for the SFRY to get involved in considering the "up-and-coming plans" of the CMEA, which was supposed to be performed "at the committees" (the Romanian representatives emphasized the "practical benefit" of establishing cooperation in April). Other than these economic reasons, it was considered at the state secretariat for foreign affairs (SSFA) that "prolonging the answer to COMECON's Secretariat would surely [...] get interpreted negatively" and would be "opposite to our endeavors for better political and economic relations with this area." 29

Despite the lack of any serious remarks about the draft Agreement, justifiable economic reasons for the answer to be delivered before the COMECON's EC meeting, as well as, the awareness that postponing the answer could be negatively interpreted, the Yugoslavs did not send it to COMECON's Secretariat promptly. Using as an excuse the lack of time for a more detailed consideration of the project, Mladen Sekicki, the eco-

28 DAMSP, PA, 1964, f. 181, dos. 12, 414632, Ambasada u Moskvi, DSIP-u, 2. 4. 1964; РГАЭ, Ф. 561, Оп. 48, Д. 239, Л. 9, И. о. Секретаря СЭВ И. Ружичка - Постоянным Представителям стран в СЭВ, 3.4.1964; Ibid, Л. 10, И. Ружичка - Послу СФРЮ Ц. Миятовичу, 2. 4. 1964; Л. 11-12, Памятная записка о беседе Й. Ружички с Ц. Миятовичем от 2. 4.1964.

29 AJ, 130-656-1087, Naša saradnja sa SEV-om. Nacrt Sporazuma između SEV-a i Vlade SFRJ o učestvovanju SFRJ u radu organa SEV-a, 10. 4. 1964; DAMSP, PA, 1964, f. 181, dos. 11, 46870, Ambasada u Bukureštu, DSIP-u, 3. 3. 1964; Ibid, 49747, Ambasada u Sofiji, DSIP-u, 19. 3. 1964; Ibid, dos. 12, 413876, Izveštaj o pregovorima sa SEV-om, 13. 2. 1964; Ibid, 415627, Papić (iz Ženeve), DSIP-u, 4. 4. 1964; Ibid, 417209, Beleška o pripremama za razmatranje nacrta sporazuma o saradnji sa SEV-om, 20. 4. 1964; Ibid, 419639, Ambasada u Bukureštu, DSIP-u, 30. 4. 1964; Ibid, 425350, Ambasada u Bukureštu, DSIP-u, 11. 6. 1964. 
nomic advisor at the Yugoslav Embassy in Moscow, delivered the "just received information from Belgrade" to the COMECON's Secretariat by phone on April 21 and sent an apology because Yugoslavia "cannot announce its opinion about the Agreement project" for the next meeting of the COMECON's EC. ${ }^{30}$ The reviewed documents do not give us a direct answer to the question of why Yugoslavia was prolonging its response and slowing down the process of concluding the Agreement for several months. Officially, the Yugoslav side claimed that "due to the shortness of time, the FEC could not make any remarks on [...] the draft or answers to the questions of how it would be signed." ${ }^{31}$ Given the lack of any serious remarks about the content of the draft Agreement, it was obvious that the stated explanation was an excuse and not a real reason. Such a decision could only have been motivated by a political reason (in this case as well, the intermingling of "politics" and "economy" could not have bypassed SFRY and CMEA relations).

A broader view of Yugoslavia's foreign policy orientation speaks about the fact that the Yugoslavs, while deciding on such a matter, could have had in mind that they did not want to send a "signal" to the Western world and/or partners from the non-aligned countries of the Third World, that the SFRY was getting closer to the socialist camp. ${ }^{32}$ Documents indicate that Belgrade was not overly "concerned" with the stance of the West on that matter. ${ }^{33}$ Unlike this, Yugoslav foreign policy in 1964 was focusing a lot of attention to the preparation of the Second Conference of Heads of States or Governments of the Non-Aligned Countries (Cairo, October 5-10, 1964) and - by all odds - it was the main reason why the decision on establishing cooperation with the CMEA was prolonged during the preparation of the "summit." ${ }^{34}$ In the period when Josip Broz Tito invested great

30 РГАЭ, Ф. 561, Оп. 48, Д. 242, Л. 83, Памятная записка, А. Быков, 21. 4. 1964.

31 DAMSP, PA, 1964, f. 181, dos. 12, 419639, DSIP - predstavništvima u Moskvi, Varšavi, Pragu, Sofiji i Berlinu, 8. 5. 1964.

32 During the period they were getting closer to the COMECON, Belgrade was careful not to disturb relations with the West in that way, or to jeopardize its position in the "Non-Aligned Movement." РГАНИ, Ф. 5, Оп. 49, Д. 519, Л. 292, О советско-югославских экономических отношениях, 15. 12. 1962. Exactly because of the "outside-ofthe-Eastern-Bloc position" they were taking and intending to preserve, the full membership in the COMECON was unacceptable for Yugoslavia. DAMSP, PA, 1962, f. 99, dos. 1, 419972, Ambasada u Varšavi, DSIP-u, 16. 6. 1962.

33 DAMSP, PA, 1964, f. 181, dos. 12, 417209, Beleška o pripremama za razmatranje nacrta sporazuma o saradnji sa SEV-om, 20.4.1964.

34 Belgrade expressed similar precaution a couple of years earlier, during the preparations for the Conference of the Non-Aligned Movement about the problems of economic growth (Cairo, July 9-18, 1962), which coincided with the actualization of re- 
efforts to mitigate the differences in the points of view among the outsideof-the-bloc states, ${ }^{35}$ the connection of the SFRY and the CMEA was not entirely "opportune" (in other words: the Yugoslavian aspirations toward "creating" a path of "Non-Alignment" did not exactly go hand in hand with establishing cooperation with a par-excellence bloc organization, such as the CMEA). Because of that Belgrade aspired to avoid "the over-emphasized manifestation character" while concluding the Agreement. Because of that Yugoslavs were pointing out the "business character" of the cooperation between the SFRY and the CMEA and emphasizing the fact that Yugoslavia did not become a member of that "integration group." ${ }^{36}$

It was not until mid-July that an instruction was given to the Yugoslav diplomats in Moscow to announce to N. Fadeyev that the "Federal Executive Council considered and with some minor remarks [...] adopted the draft agreement on the participation of the SFRY within the organs of the CMEA." Since it was not a matter of any "relevant changes," it was noted that "there is no need for new negotiations." In support of the assumption that Belgrade slowed down the signing of the Agreement with the CMEA for political reasons - other than prolonging the answer itself - also speaks to the fact that it was noted to the Yugoslav diplomats that they "should not demand the speeding up of the process," but "on the contrary, that we have an interest for everything to move on gradually and according to regular procedure." Another matter that shows Yugoslavia's restraint is Belgrade's view that "it doesn't suit us that the Agreement was signed by the deputy premiers and that we give the matter an over-emphasized manifestation character" (on the contrary, the FEC had suggested "the exchange of notes as a form of regulating [...] the cooperation"). ${ }^{37}$ With a one-week "delay," the Yugoslav ambassador informed the COMECON Secretariat, on June 26, that "the Yugoslav side does not have any substantial remarks" about the Agreement project that it received on April

lations between the SFRY and the COMECON. DAMSP, PA, 1962, f. 99, dos. 2, 416143, Cirkularni telegram DSIP-a, 18. 5. 1962.

35 Vladimir Petrović, Titova lična diplomatija. Studije i dokumentarni prilozi, (Beograd: Institut za savremenu istoriju, 2010), 183-185; Dragan Bogetić, „,Sukob Titovog koncepta univerzalizma i Sukarnovog koncepta regionalizma na Samitu nesvrstanih u Kairu 1964", Istorija 20. veka 2/2017, 101-118.

36 DAMSP, PA, 1964, f. 181, dos. 12, 428879, DSIP, Ambasadi SFRJ u Bukureštu, 11. 7. 1964; Ibid, dos. 13, 431597, Izvod iz zapisnika sa sednice SIV-a u užem sastavu, održane 17. 7. 1964; Ibid, 429890, Cirkularni telegram DSIP-a - svim predstavništvima, 24. 7. 1964; Ibid, 433771, DSIP, Ambasadi u Moskvi, 3. 9. 1964.

37 DAMSP, PA, 1964, f. 181, dos. 12, 420799, DSIP, Ambasadi u Moskvi, 18. 6. 1964; Ibid, 428879, DSIP, Ambasadi u Bukureštu, 11. 7. 1964. 
2. The harmonization of the Agreement text followed, during which the COMECON's Secretariat "literally accepted all of the FEC's remarks" (the inviting to the "international socialist division of works" was taken out of the Agreement preamble). ${ }^{38}$

Regarding the completion of negotiations, in early July, Belgrade told its diplomats in Moscow that "we do not have anything against delaying the process of finalizing the agreement procedure, [...] but we do not want the other side (CMEA, SU [Soviet Union]) to get the impression that it is some kind of a maneuver on our side, in any way." "If it is possible to prolong the agreement on cooperation in any way that would appear natural, you can delay sending the note. If, however, you deem that it could or would be interpreted by our partner in any way as our intentional delay or diversion, then it is better to send the note" - the SSFA stated. ${ }^{39}$ A day later, on July 2, the Yugoslav diplomats did however send the note to the COMECON's Secretariat with a harmonized agreement text (it was necessary because of notifying the government members of the CMEA in a timely way about the XIII meeting of the EC). ${ }^{40}$ At the XIII Meeting of the COMECON's EC on July 16, the changes in the text of the Agreement were approved, i.e. the decision was made on concluding the Agreement with the SFRY. Since the CMEA did not conclude agreements by exchanging notes, it was suggested to the Yugoslavs that the "agreement could be concluded with an exchange of letters" and that it should take effect on the "day of the exchange."11 On the other hand, on July 17, 1964, the FEC brought along a decision about the Agreement temporarily taking effect on August 1, and that it would "definitely take effect when the FEC rat-

38 РГАЭ, Ф. 561, Оп. 44c, Д. 12, Л. 133-135, Й. Ружичка - Постоянным Представителям стран в СЭВ, 3. 7. 1964; Ibid, Л. 136-137, Памятная записка о беседе Й. Ружички с Ц. Миятовичем от 26. 6. 1964; Ibid, Л. 138-139, Уточнения проекта Соглашения между Советом Экономической Взаимопомощи и Правительством Социалистической Федеративной Республики Югославии об участии СФРЮ в работе органов СЭB; DAMSP, PA, 1964, f. 181, dos. 12, 427870, Ambasada u Moskvi, DSIP-u, 26. 6. 1964; Ibid, 426570, Kabinet Mirka Tepavca, Ambasadi u Moskvi, 27. 6. 1964; Ibid, dos. 13, 427940, Ambasada u Moskvi, DSIP-u, 27. 6. 1964.

39 Ibid, 427940, Kabinet državnog sekretara, Ambasadi u Moskvi, 1. 7. 1964.

40 РГАЭ, Ф. 561, Оп. 44c, Д. 30, Л. 62, Ц. Мијатовић, Н. В. Фадејеву, 2. 7. 1964; Ibid, Л. 63-68, Споразум између Владе СФРЈ и СЕВ-а о учествовању СФРЈ у раду органа CEB; Ibid, Л. 69, Ц. Миятович, Н. В. Фаддееву, 2. 7. 1964; Ibid, Л. 70-75, Соглашение между Советом Экономической Взаимопомощи и Правительством Социалистической Федеративной Республики Югославии об участии СФРЮ в работе органов СЭВ (Проект); DAMSP, PA, 1964, f. 181, dos. 13, 427940, Ambasada u Moskvi, DSIP-u, 27. 6. 1964; Ibid, 428244, Ambasada u Moskvi, DSIP-u, 2. 7. 1964.

41 DAMSP, PA, 1964, f. 181, dos. 13, 432414, Ambasada u Moskvi, DSIP-u, 5. 8. 1964. 
ified it and the session of the CMEA approved it." On that occasion "the draft statement about the Agreement's conclusion" had also been accepted and the Yugoslav Government especially pointed out that the statement should "emphasize the mutual benefit and interest, so that the business part was emphasized as much as possible in the interpersonal relations." ${ }^{42}$

In that period, practically "all matters" - as was stated by Pirot Jaroszewicz - were "clarified" 43 and the rest of "the procedure" was a mere formality. However, the Agreement was not concluded in early $\mathrm{Au}-$ gust, as was expected by the Yugoslavs, and the procedure was prolonged until mid-September. The Yugoslav side agreed with the proposal on concluding the Agreement by exchanging letters (not notes), and during August and September further consultations ensued, the harmonizing of the agreement text and "refinement" of the translation (it is possible that the stay of N. V. Fadeyev on vacation during August had a certain influence on prolonging the Agreement finalization). It was agreed that two letters of the same content would be exchanged ("with agreements attached") and that they should represent "two original contracts." 4

Finally, the exchange of letters was performed on September 17, at the COMECON's Secretariat. ${ }^{45}$ During the toast and the conversations at the reception, the Yugoslav diplomats noticed Fadeyev's "endeavor to emphasize and underline the political character of the agreement and point out the significance it had for promoting relations among the socialist countries." Stating how he was also talking about "cooperation on the principles of internationalism and successes in the competing of the two systems," Gorski pointed out that in the initial text of his toast, the

42 AJ, 130-656-1087, Izvod iz zapisnika sa sednice SIV-a u užem sastavu, održane 17. 7. 1964; DAMSP, PA, 1964, f. 181, dos. 13, 429890, DSIP, Ambasadi u Moskvi, 24.7. 1964.

43 DAMSP, PA, 1964, f. 181, dos. 13, 431854, Ambasada u Varšavi, DSIP-u, 29. 7. 1964.

44 DAMSP, PA, 1964, f. 181, dos. 13, 429890, DSIP, Ambasadi u Moskvi, 11. 8. 1964; Ibid, 433771, Ambasada u Moskvi, DSIP-u, 17. 8. 1964; Ibid, DSIP, Ambasadi SFRJ u Moskvi, 25. 8. 1964; Ibid, DSIP, Ambasadi SFRJ u Moskvi, 3. 9. 1964; Ibid, 434768, Ambasada u Moskvi, DSIP-u, 28. 8. 1964; Ibid, 435325, Ambasada u Moskvi, DSIP-u, 8. 9. 1964; Ibid, 436943, Ambasada u Moskvi, DSIP-u, 12. 9. 1964; РГАЭ, Ф. 561, Оп. 48, Д. 242, Л. 180, Запись бедеды исполняющего обязанности Секретаря СЭВ т. Н. Табакопола с Ф. Горским 13. 8. 1964.

45 „Закључен споразум о учешћу Југославије у раду неких органа СЕВ“, Борба, 18. 9. 1964, 1. - The public was informed about the concluded Agreement with a joint press release. РГАЭ, Ф. 561, Оп. 48, Д. 243, Л. 79-80, Расширяется сотрудничество социалистических стран в рамках Совета Экономической Взаимопомощи (Сообщение для печати), 16. 9. 1964; „Заједничко саопштење о споразуму“, Борба, 18. 9. $1964,1$. 
"socialist camp" was explicitly mentioned, but was left out in the final text. ${ }^{46}$ In both Fadeyev's and Gorski's speech, the economic reasons for the cooperation of the SFRY and the CMEA were pointed out, but certain matters were differently emphasized. In the introductory parts of Fadeyev's speech - as stated by Gorski - he mentioned the economic cooperation among the socialist countries along the "principles of socialist internationalism" and pointed out that the "world system of socialism" is strengthening its economic powers and advancing toward victory "in peaceful competition with capitalism" (the Yugoslav press did not convey that part of the speech of the COMECON's secretary!) Also, he pointed out that the CMEA was an "open organization, whose doors are open to all countries that share the aims and principles of the Council" and mentioned how the statute of the COMECON provided "wide opportunities" for cooperation with countries that are not members of the organization (as an "imposing" confirmation of the above stated, he mentioned the concluded Agreement). On the other hand, Gorski dedicated his entire speech to the aspect of economic cooperation between the SFRY and the CMEA members, mentioning by the way, how Yugoslavia was conducting a "policy of developing versatile economic cooperation with all countries." The Yugoslav chargé d'affaires pointed out that the Agreement "opens new possibilities" for the cooperation of the SFRY and the CMEA and expressed confidence that it would "contribute to the further expansion of fruitful economic cooperation between the SFRY and the COMECON member-states and raise it on a new level." ${ }^{47}$

It was stated in the exchanged letters that both sides, "according to the previous agreement," apply the Agreement "temporarily" from September 17, 1964 and that it would be "valid" and put into effect when the documents on its ratification have been exchanged. ${ }^{48}$ In the Agreement text, specifically the preamble, there are 11 articles about principles and ways of cooperation, which were pointed out and harmonized during the negotiations conducted at the beginning of the year. It was stated in the Agreement's preamble that the SFRY Government and the CMEA have started its finalization "with the wish to contribute to the further development of economic cooperation and to resolving economic problems, which have a

46 DAMSP, PA, 1964, f. 181, dos. 13, 438296, Ambasada u Moskvi, DSIP-u, 23. 9. 1964.

47 Ibid, 439955, Govori N. Fadejeva i F. Gorskog; „Закључен споразум о учешћу Jyгославије у раду неких органа СЕВ“, Борба, 18. 9. 1964, 1.

48 РГАЭ, Ф. 561, Оп. 48, Д. 243, Л. 8, Н. Фаддеев, Ф. Горски, 17. 9. 1964; Ibid, Л. 9, Ф. Горски, Н. Фаддееву, 17. 9. 1964; DAMSP, PA, 1964, f. 181, dos. 14, 440004, Faddeev, F. Gorskom, 17. 9. 1964; Ibid, F. Gorski, N. Fadejevu, 17. 9. 1964. 
mutual interest for SFRY and the COMECON member-countries"; the principles of cooperation between the SFRY and the CMEA were pointed out ("complete equality, respect of sovereignty, national interests, and mutual benefit") and the legal basis for the conclusion (Article X of COMECON's Statute). In the 11 articles from the Agreement, the models of involvement of the SFRY within the organs of the CMEA were specified, as well as the ways in which the cooperation between Yugoslavia and the socialist economic integration was to be carried out. ${ }^{49}$ It should be especially emphasized that the Agreement provided a broad basis for cooperation: the possibility of widening the "active" cooperation to "other areas" (Art. 1) was stipulated, and the opportunity was given to the SFRY to "join the recommendations and decisions that were decided upon earlier by the organs of the COMECON" (Art. 5), and the possibility of "altering or amending" the Agreement based on a "mutual agreement" (Art. 11) was also allowed..$^{50}$

49 More specifically, the following matters were regulated with the Agreement: areas of active cooperation ("foreign trade, currency-financial relations, black and colored metallurgy, mechanical engineering, chemical industry and coordination of scientific and technical research") and the manner of determining questions of "common interest" (Art. 1); the involvement of SFRY representatives in different organs of COMECON (Art. 2); the manner of work and authorizations of Yugoslav representatives in the COMECON organs, the manner of making recommendations and decisions in the COMECON, which are related to questions of "common interest" (Art. 3); various obligations of the SFRY regarding the adoption and usage of the COMECON's recommendations and the realization of the Agreement (Art. 4); the presence of Yugoslav representatives "as observers" at the COMECON committee sessions (Art. 6); different "procedural questions" about the involvement of the Yugoslav representatives in the work of the COMECON (Art. 7); the involvement of experts from the SFRY in preparing materials and elaboration of "questions of mutual interest" at the hearings of the COMECON organs (Art. 8); "the secrecy of materials and information" that the two sides would exchange (Art. 9); resolving the question that "come up" during the implementation of the Agreement "through negotiations" (Art. 10); the ratification and mode of canceling the Agreement - which was not time limited - with a deadline of "at least 6 months in advance" (Art. 11). РГАЭ, Ф. 561, ОП. 48, Д. 243, Л. 10-15, Соглашение между Советом Экономической Взаимопомощи и Правительством Социалистической Федеративной Республики Югославии об участии СФРЮ в работе органов СЭB; DAMSP, PA, 1964, f. 181, dos. 14, 440004, Sporazum između Vlade SFRJ i SEV-a o učestvovanju SFRJ u radu organa SEV.

50 DAMSP, PA, 1964, f. 181, dos. 14, 440004, Sporazum između Vlade SFRJ i SEV-a o učestvovanju SFRJ u radu organa SEV. - Thanks to such an approach, the SFRY expanded its area of active participation in the decades to come, to 23 permanent organs of the COMECON (it also participated in the work of six "specialized economic associations,” which functioned within the COMECON). Ћирић, „Привредно-правни аспекти“, 200, 202; Nikola Filipović, „Uvodno izlaganje na jugoslovenskom naučno-stručnom skupu posvećenom 20-godišnjici Sporazuma o saradnji između SFRJ i SEV-a“, Saradnja SFRJ-SEV, 22; Mito Pejovski, „Rezultati i perspektive multilateralne ekonomske saradnje SFRJ i zemalja-članica SEV“, Saradnja SFRJ-SEV, 34. 
In the newer literature, certain incorrect information about the conclusion and ratification of the Agreement can be found. ${ }^{51}$ For the purpose of eliminating existing doubts and clarifying the question about when the cooperation between the SFRY and the CMEA had started, we present these notes: 1) the Agreement about the participation of the SFRY in the organs of the COMECON was concluded with an exchange of letters on September 17, 1964, at the COMECON Secretariat in Moscow; 2) the FEC brought a Regulation about the ratification of the Agreement on November $13,1964^{52}$; 3) the CMEA confirmed the Agreement on the XIX session (Prague, 28. 1. - 2. 2. 1965); 4) the exchange of ratification instruments was executed on April 24, 1965 in Prague..$^{53}$ Even though the exchange of ratification instruments presented the beginning of "official cooperation" between the SFRY and the CMEA, the regulations of the Agreement "temporarily" took effect on September 17, 1964. Both Yugoslav documents and documents of the COMECON's Secretariat confirm that the Agreement had started to apply immediately after its conclusion..$^{54}$ The development of relations in the decades to come showed that, with the Agree-

51 Nenad Popović and Ondrej Jaško state, on more than one occasion, that the Agreement was "concluded in Prague" on September 17, 1964, and that the Agreement was signed in "1965." Поповић, Јашко, Спољнотрговински односи, 164-165; Ненад Поповић, Ондреј Јашко, „Српско-руске економске везе кроз историју“, Руски некропољ у Београду. Знамење историјског пријатељства, ур. Мира Радојевић, Милош Ковић, (Београд: Руски некропољ-ИПЕД, 2014), 73; Ненад Поповић, „Историјски развој српско-руских економских односа“, Србија и Русија 18141914-2014. Међународни научни скуп 13-14. октобар 2014. године, ур. Михаило Војводић, (Београд: САНУ, 2016), 406-407.

52 Incorrect information can be found in literature that the SFRY ratified the Agreement on November 30, 1964. Đukić, Ekonomska saradnja, 94, nap. 15; Lazović, Ekonomska integracija, 216, nap. 553.

53 DAMSP, PA, 1964, f. 181, dos. 14, 44004, SIV, Službi za pravne poslove DSIP-a, 14. 11. 1964; Ibid, dos. 15, 446120, Izvod iz zapisnika sa sednice SIV-a u užem sastavu, održane 13. 11. 1964; DAMSP, PA, 1965, f. 137, dos. 8, 43349, DSIP - predstavništvima SFRJ, 16. 2. 1965; Ibid, D. Besarović, Čuvaru zbirke međunarodnih ugovora, 2. 6. 1965; AJ, KPR, III-b-2-a, Referat u vezi potpisivanja ratifikacionog instrumenta Sporazuma između Vlade SFRJ i SEV-a o učestvovanju SFRJ u radu organa SEV-a, zaključenog razmenom pisama u Moskvi 17. 9. 1964, 16. 12. 1964; AJ, 130-656-1087, Izveštaj jugoslovenske delegacije o XIX zasedanju SEV-a.

54 РГАЭ, Ф. 413 (Министерство внешней торговли СССР), Оп. 31, Д. 122, Л. 60-63, Заведующий отделом внешней торговли Секретариата СЭВ В. Моисеенко, Министру внешней торговли СССР Н. Патоличеву, 20. 11. 1964; Ibid, Ф. 561, Оп. 48, Д. 243, Л. 16, Н. Фаддеев - Председателям Постоянных Комиссий, 19. 9. 1964; DAMSP, PA, 1964, f. 181, dos. 14, 443206, Zabeleška J. Stojkovića o razgovoru u Sekretarijatu SEV-a, 6. 10. 1964; Ibid, 441167, Ambasada u Moskvi, DSIP-u, 13. 10. 1964. 
ment, good "foundations" and "broad frames" were set for cooperation between the SFRY and the CMEA. ${ }^{55}$

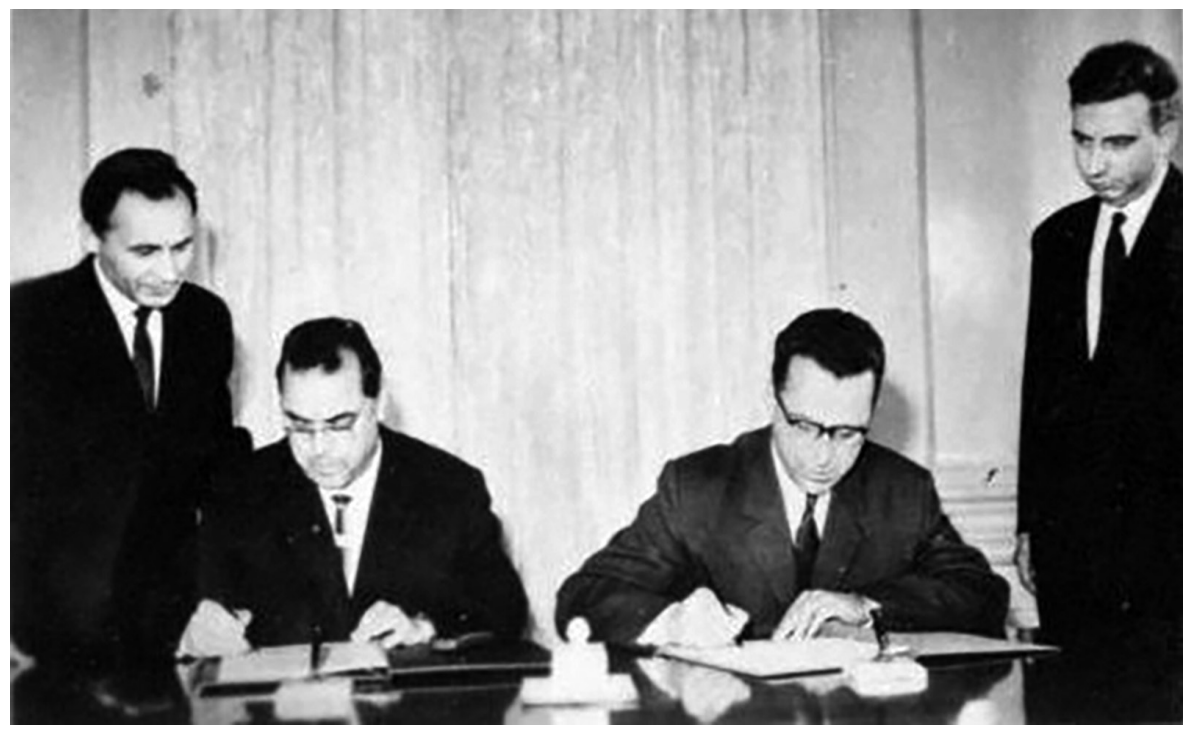

The conclusion of the Agreement on the participation of the SFRY within the organs of the COMECON, at the COMECON Secretariat in Moscow, on September 17, 1964. On the photo, N. V. Fadeyev (left) and F. Gorski (right) are putting their initials (not signing!) the pages of the Agreement. (AJ, Zbirka Tanjug (112), 205-14745, 1)

\section{Summary}

The rise of Yugoslav-Soviet relations in the first half of the 1960s had enabled the establishment of cooperation between the SFRY and the CMEA (Council for Mutual Economic Assistance, also COMECON). A number of factors were pushing Yugoslavia to get closer to the COMECON (difficulties in economic relations with the West, the strengthening of integration processes in the CMEA, the limitations of "bilateralism" in economic cooperation with the members of the CMEA). The Yugoslav desire for establishing cooperation coincided with the plans of the Kremlin to expand the CMEA. In addition, Moscow wanted to influence Yugoslav politics through

55 Lazović, Ekonomska integracija, 216; Lazović, „Razvoj SEV-a i saradnja SFRJ-SEV“, 68; Filipović, „Uvodno izlaganje“, 22; Pejovski, „Rezultati i perspektive“, 34; Slobodan Antonijević, „Dvadesetogodišnja spoljnotrgovinska saradnja Jugoslavije sa zemljamačlanicama SEV“, Saradnja SFRJ-SEV, 116. 
the CMEA and to get the SFRY closer into the fold of the "socialist camp." At the negotiations conduced in early 1964, the basic principles and modes of Yugoslavia's cooperation with the CMEA were agreed. Two forms of cooperation had been agreed: 1) "active cooperation," which implied the involvement of Yugoslavs in the works of certain commissions; 2) Yugoslavia's observer status at the sessions of the COMECON organs, which had an informative role. Due to foreign policy reasons (the preparation of the Second Conference of the Non-Aligned Movement), Belgrade kept prolonging the finalization of the Agreement for several months. Instead of being concluded in the spring, the Agreement on the participation of the SFRY in the organs of the COMECON was finalized on September 17, 1964. The SFRY did not become a member in that way, but created the preconditions for cooperation on matters of "mutual interest." The Agreement was broadly conceived and represented a good basis for cooperation between the SFRY and the CMEA in the decades to come.

\section{Sources and Literature}

- Arhiv Jugoslavije. Fondovi: 130, Savezno izvršno veće; 837, Kabinet predsednika Jugoslavije.

- Diplomatski arhiv Ministarstva spoljnih poslova Republike Srbije. Fond Politička arhiva, Istočnoevropske zemlje.

- Rossijskij gosudarstvennyj arhiv jekonomiki: Fond 413, Ministerstvo vneshnej torgovli SSSR; Fond 561, Sekretariat Soveta jekonomicheskoj vzaimopomoshhi.

- $\quad$ Rossijskij gosudarstvennyj arhiv novejshej istorii. Fond 5 Apparat CK KPSS.

- Bogetić, Dragan. „Uvođenje američkih ekonomskih restrikcija Jugoslaviji tokom 1962 - ukidanje statusa 'najpovlašćenije nacije'.' Istorija 20. veka 1/2009, 87-105.

- Bogetić, Dragan. „Sukob Titovog koncepta univerzalizma i Sukarnovog koncepta regionalizma na Samitu nesvrstanih u Kairu 1964". Istorija 20. veka 2/2017,101-118. doi: 10.29362/ist20veka.2017.2.bog.101-118

- Gladysheva, Anna Sergeevna. „Sovetskie plany jekonomicheskoj integracii v ramkah SJeV i pozicija rumynskogo rukovodstva (seredina 1950-h-seredina 1960-h gg.)“. Jelektronnyj nauchnoobrazovatel'nyj zhurnal Istorija, 2015, T. 6, Vypusk 11 (44), 1-29. Accessed 16.3.2017. http://history.jes.su/ s207987840001341-4-1, doi: 10.18254/S0001341-4-1 (cyrillic)

Ćirić, Aleksandar. „Privredno-pravni aspekti dvadesetogodišnjice saradnje SFRJ-SEV“. Zbornik radova Pravnog fakulteta u Nišu XXV, ur. Miroslav Miljković, 197-211. Niš: Pravni fakultet Univerziteta u Nišu, 1985. (cyrillic) doi: 10.3935/zpfz.69.56.12

- Đukić, Srećko. Ekonomska saradnja SFRJ SEV. Beograd: Zadruga, 1984. 
- Igrutinović, Milan J. „Jugoslovensko-američki ekonomski odnosi (19541968)“. Doktorska disertacija, Univerzitet u Beogradu, Filozofski fakultet, Odeljenje za istoriju, 2018. (cyrillic)

- Jaško, Ondrej, Nenad Popović. Spoljnotrgovinski odnosi i perspektive privredne saradnje Ruske Federacije i Republike Srbije. Beograd: Srpski ekonomski centar, 2010. (cyrillic)

- Jaško, Ondrej, Nenad Popović. „Srpsko-ruske ekonomske veze kroz istoriju“. Ruski nekropolj u Beogradu. Znamenje istorijskog prijateljstva, ur. Mira Radojević, Miloš Ković, 64-83. Beograd: Ruski nekropolj-IPED, 2014. (cyrillic)

- Lazović, Budimir I. Ekonomska integracija u okviru Savjeta za uzajamnu ekonomsku pomoć. Beograd: Vaša knjiga, 2005.

- $\quad$ Lipkin, Mihail Arkad'evich. „'Mirovoj kooperativ narodov': Sovet jekonomicheskoj vzaimopomoshhi, kotoryj pytalsja postroit' N. S. Hrushhev". Novyj istoricheskij vestnik 4/2017, 121-144. (cyrillic)

- $\quad$ Lipkin, Mihail Arkad'evich. „Sovet Jekonomicheskoj Vzaimopomoshhi i sovremennye trendy v izuchenii XX veka: K 70-letiju obrazovanija SJeV“. Studia Slavica et Balcanica Petropolitana 2/2019, 56-66. (cyrillic)

- Obadic, Ivan. „A troubled relationship: Yugoslavia and the European Economic Community in détente“. European Review of History 2/2014, 329-348. doi: 10.1080/13507486.2014.888709

- Petrović, Vladimir. Titova lična diplomatija. Studije i dokumentarni prilozi. Beograd: Institut za savremenu istoriju, 2010.

- Popović, Nenad. „Istorijski razvoj srpsko-ruskih ekonomskih odnosa“. Srbija i Rusija 1814-1914-2014. Međunarodni naučni skup 13-14. oktobar 2014. godine, ur. Mihailo Vojvodić, 399-415. Beograd: SANU, 2016. (cyrillic)

- $\quad$ Saradnja SFRJ-SEV. Principi-aktuelna pitanja-perspektive. Materijali jugoslovenskog naučno-stručnog skupa povodom 20 godina saradnje SFRJ-SEV, ur. Ljubivoje Prvulović. Beograd: Institut za međunarodnu politiku i privredu, 1987.

- $\quad$ Tripković, Đoko. Jugoslavija-SSSR 1956-1971. Beograd: ISI, 2013.

- Vresk, Sonja. „Sovetskij Sojuz i Jugoslavija: problemy politicheskogo vzaimodejstvija v 1955-1971 gg." Dissertacija na soiskanie uchenoj stepeni kandidata istoricheskih nauk, Sankt-Peterburgskij gosudarstvennyj universitet, 2011. (cyrillic)

- Borba 1964. (cyrillic) 


\title{
Резиме
}

\author{
Момир Н. Нинковић
}

\section{Успостављање сарадње СФРЈ и СЕВ-а 1964. године}

\begin{abstract}
АПстРАкт: У чланку су анализирани мотиви за успостављање сарадње Југославије и Савета за узајамну економску помоћ (CEB). Приказани су ток преговора и закључивање Споразума о учествовању Југославије у раду органа CEB-а. Рад је заснован на необјављеним документима архива у Републици Србији и Руској Федерацији и релевантној литератури.

КљУчнЕ РЕчи: Југославија, Савет за узајамну економску помоћ, Совјетски Савез, економска интеграција
\end{abstract}

Успон југословенско-совјетских односа у првој половини шездесетих је омогућио успостављање сарадње СФРЈ и Савета за узајамну економску помоћ. Низ фактора је упућивао Југославију на приближавање Савету (тешкоће у економским односима са Западом, јачање интеграционих процеса у CEB-у, ограничења „билатерализма“ у економској сарадњи са чланицама ове организације). Југословенска тежња за успостављањем сарадње се подударала са плановима Кремља за ширење CEB-а. Осим тога, у Москви су прижељкивали да путем Савета утичу на југословенску политику и да СФРЈ приближе „лагеру“. На преговорима вођеним почетком 1964. договорени су основни принципи и начини југословенске сарадње са CEB-ом. Договорена су два облика сарадње: 1) „активна сарадња“, која је подразумевала учешће Југословена у раду одређених комисија; 2) „посматрачко“ присуство Југословена на заседањима органа CEB-a, које је имало информативну улогу. Због спољнополитичких разлога (припреме Друге конференције неангажованих држава), Београд је за више месеци пролонгирао закључивање споразума. Уместо у пролеће, Споразум о учествовању СФРЈ у раду органа СЕВ-а је закључен тек 17. септембра 1964. године. Југославија на тај начин није ступила у чланство Савета, већ је створила предуслове за сарадњу по питањима која су представљала „заједнички интерес“. Споразум је био широко замишљен и представљао је добру основу за сарадњу СФРЈ и СЕВ-а у наредним деценијама. 
